\title{
PROBING BREAST CANCER THERAPEUTIC RESPONSES BY DNA CONTENT PROFILING
}

\author{
B.I. Gerashchenko ${ }^{1 *}$, K. Salmina ${ }^{2}$, J. Eglitis ${ }^{3}$, J. Erenpreisa ${ }^{2}$ \\ 1 - R.E. KAVETSKY INSTITUTE OF EXPERIMENTAL PATHOLOGY, ONCOLOGY AND RADIOBIOLOGY \\ OF THE NATIONAL ACADEMY OF SCIENCES OF UKRAINE, KYIV, UKRAINE \\ 2 - LATVIAN BIOMEDICAL RESEARCH AND STUDY CENTRE, RIGA, LATVIA \\ 3 - UNIVERSITY OF LATVIA, RIGA, LATVIA
}

Background. Discrepancies in the interpretation of breast cancer therapeutic responses still exist mainly because of lack of standardized assessment criteria and methods.

Objective. DNA content profiling of cells in the affected (cancerous) tissue before and after neoadjuvant chemotherapy (NAC) was applied to facilitate interpretation of therapeutic responses.

Methods. Both diagnostic biopsy and operation materials representing the tissue of primary tumors surgically removed after NAC were subjected to DNA image cytometry. Polyploidy and aneuploidy in DNA histograms were evaluated with a prognostic Auer typing. Stemline DNA index (DI) values and percentages of cells that polyploidize (>4.5C) were also determined. Immunofluorescence staining was applied to evaluate proliferation (Ki-67), invasiveness (CD44), and self-renewal factors characteristic for stem cells (SOX2 and NANOG).

Results. DNA content profiles of 12 breast cancer cases, of which 7 were triple-negative, revealed the features of tumor non-responsiveness to NAC in 7 cases, of which 5 were triple-negative. Among non-responsive cases there were 3 cases that showed enhanced polyploidization, suggesting the negative NAC effect. Near-triploid (DI=1.26-1.74) triple-negative cases were determined as most resistant to NAC. Cycling near-triploid cells may contribute to the excessive numbers of $>4.5 \mathrm{C}$ cells. Polyploid cells were positive for Ki-67, CD44, SOX2, and NANOG.

Conclusions. DNA content profiling data provide additional helpful information for interpreting therapeutic responses in NAC-treated breast cancers. Polyploid tumor cells possessing stem cell features can be induced by NAC. Because NAC effects in some cases may be unfavorable, the use of the further treatment strategy should be carefully considered.

KEY WORDS: breast cancer; polyploid cells; near-triploidy; DNA content profiling; therapeutic response; cancer stem cells.

\section{Introduction}

Neoadjuvant therapy that was initially designed for the preoperative treatment of patients with locally advanced breast cancer [1] presently provides a good opportunity to evaluate therapeutic response of primary tumors and customize subsequent conventional non-surgical treatment [2-5]. Therapeutic response is usually assessed by means of histological examination of the affected breast tissue stained with hematoxylin and eosin. To date, most histological criteria consider the absence of invasive cancer cells in the breast and regional lymph nodes as a pathologic complete response $(p C R)[3,4]$. Contrary to the patients, who have partial or no response, those patients, who achieve $\mathrm{pCR}$, largely have favo-

Corresponding author*: Bogdan I. Gerashchenko, MD, Ph.D. R.E. Kavetsky Institute of Experimental Pathology, Oncology and Radiobiology of NASU, 45 Vasylkivska Str., Kyiv 03022, Ukraine

Phone: +38044 2571177, FAX: +380442581656

E-mail: biger63@yahoo.com rable prognosis (improved long-term, diseasefree, and overall survival) [5]. Although the histological assessment of therapeutic responses significantly helps to determine prognosis in breast cancer, the problem caused by discrepancies in the interpretation of results obtained from different pathologists remains unresolved mainly because of lack of standardized assessment criteria and methods [4, 5]. Moreover, the term pCR still needs to be applied in a consistent, standardized manner [6].

Breast cancer as many other solid tumors is predisposed to high degrees of aneuploidy (abnormal chromosome number) $[7,8]$ that correlates with the resistance to anti-cancer treatment and poor prognosis [9]. To minimize misinterpretations in histopathologic scoring of therapeutic responses, DNA content profiling of cells in the affected breast tissue before and after neoadjuvant therapy seems to be a good option since this technique is capable of detecting tumor cell DNA aneuploidy that may 
often be unseen by histopathologists. In other words, the advantage of the technique is in detection of very small numbers of aneuploid tumor cells in a large cohort of analyzed cells. In this regard, the intra-tumor genetic diversity that can potentially be manifested in clonal heterogeneity is worth mentioning $[10,11]$. There are situations when in a tumor the drugsensitive dominant clones can be eliminated, while the minor resistant clones or sub-clones can be hiding in a dormant state followed by accelerated cell proliferation. Also, to date, the issue of detecting and quantifying the resistant tumor cells that polyploidize in response to genotoxic therapies is of pivotal importance $[12,13]$. Cytometric determination of DNA content in tissue specimens for detecting malignancies, monitoring responses to therapy, and prognosing disease outcome is very important and demanding $[12,14]$. Notably, cell nuclei isolated from aneuploid-gated distributions by means of fluorescence activated cell sorting can be subjected to single-cell DNA and RNA sequencing to study breast cancer chemoresistance evolution [15].

In this study, the image cytometry-based DNA content profiling of cells of the affected breast tissues of women predominantly with locally advanced Stage III disease before and after neoadjuvant chemotherapy (NAC) with paclitaxel and doxorubicin was performed. DNA histograms were categorized into 4 types (I-IV) according to Auer [16] to estimate the grade of malignancy for diagnostic and prognostic purposes. Positions of stemline DNA aneuploidy peaks as well as the number of polyploidizing cells $(>4.5 \mathrm{C})$ were taken into account while analyzing DNA content profiles. The DNA content profiling data were compared with Miller-Payne histopathologic grades specifically designed for evaluation of therapeutic responses [17]. One of the therapy-resistant cases that showed extensive polyploidization was chosen for immunocytochemical staining to evaluate cell proliferation (Ki-67), invasiveness (CD44), and self-renewal factors typical for stem cells (SOX2 and NANOG).

\section{Methods}

Patients and clinico-pathologic information

The study involved 12 breast cancer patients (age range: 33-75), who underwent diagnostic procedures at the Latvian Oncology Centre of the Riga East University Hospital in 2014 and 2015. The tissue specimens were collected after the patients' informed consent was obtained in accordance with the regulations of the Committee of Medical Ethics of Latvia. The clinico-pathologic information about these patients, such as staging (ranged from I to IV), anatomic extent of disease according to TNM classification, overall grading (ranged from 1 to 3), proliferation status (based on scoring of Ki-67-positive cells in biopsies before treatment) and the status of ER, PR and HER2 receptors, was obtained from the aforementioned clinics. In the study group, 11 patients suffered from locally advanced breast cancer (predominantly Stage III disease). A case was diagnosed as triple-negative breast cancer (TNBC) if lack of ER and PR expression was accompanied by lack of HER2 expression as confirmed by commercial HercepTest (Dako, Glostrup, Denmark) showing HER2 levels at 0 or $1+$. There were 7 cases diagnosed as TNBC. Such an excessive number of TNBC cases were collected intentionally because they were expected to be resistant to NAC. After completion of diagnostic procedures, the patients underwent 3-9 courses of NAC with standard doses of paclitaxel and doxorubicin followed by surgical removal of the affected tissue. NAC effects (therapeutic responses) were evaluated by Miller-Payne histopathologic grading system [17]. In brief, this grading system based on the comparison of tumor cellularity of the core biopsy (before NAC) with that of the resected tumor (after NAC) is presented as follows: grade 1 - no reduction in overall cellularity; grade 2 - a minor loss of tumor cells $(<30 \%)$; grade 3 - moderate loss $(30-90 \%)$; grade 4 - a significant loss $(>90 \%)$; and grade 5 - no residual invasive cancer.

\section{DNA image cytometry}

The samples of diagnostic core biopsy or operation material (resected breast tissue specimens) were prepared on poly-L-lysinecoated microscope slides (Thermo Fisher Scientific, Waltham, MA, USA) and stained with a stoichiometric DNA dye toluidine blue (TB; Thermo Fisher Scientific) according to the published procedures $[18,19]$. In brief, once samples had been fully air-dried on slides, they were fixed in acetone/ethanol mixture (1:1) for at least 30 min at $4{ }^{\circ} \mathrm{C}$ and dried again. Samples were treated with $5 \mathrm{~N} \mathrm{HCI}$ for 20 min at room temperature, washed in a distilled water $(5 \times 1 \mathrm{~min})$, then stained with $0.05 \%$ TB in $50 \%$ McIlvain citrate-phosphate buffer ( $\mathrm{pH} 4.0)$. Immediately after staining, samples were rapidly washed in distilled water (3 times by dipping) and promptly blotted with absorbing sheets of paper followed by dehydration in 
butanol $\left(2 \times 3 \mathrm{~min}\right.$ at $\left.37^{\circ} \mathrm{C}\right)$. Samples were then immersed in xylene $(2 \times 3 \mathrm{~min}$ at room temperature) and embedded in DPX mounting medium (Sigma-Aldrich, St. Louis, MO, USA).

Digital images of at least 200 randomly selected and undistorted cell nuclei were collected with $100 \times$ objective magnification using Ergolux L03-10 microscope (Leitz, Germany) equipped with DXC-390P color video camera (Sony, Tokyo, Japan) calibrated in the green channel. DNA content per cell nucleus was measured as integral optical density using Image-Pro Plus 4.1 software (Media Cybernetics, Rockville, MD, USA). DNA content histograms were analyzed in accordance with the basic performance standards of diagnostic image cytometry [20]. DNA peaks were identified as aneuploid, if they deviated more than $10 \%$ from the normal diploid ( $2 \mathrm{C}$ in $\mathrm{G}_{1}$ ) or tetraploid ( $4 \mathrm{C}$ in $G_{2}$ ) region ( $10 \%$ is the estimated integral error of the method). As a reference for locating normal $2 \mathrm{C}$ peaks, the nuclei of leukocytes persisting in a sample were analyzed as well. To classify breast cancer DNA content histograms, the approach proposed by Auer et al. [16] was used. For example, the histograms characterized by a single peak in 1.5-2.5C region (diploid and near-diploid region) were classified as type I, whereas the histograms characterized by a single peak in 3.5-4.5C region (tetraploid and near-tetraploid region) but sometimes supplemented with an additional peak in 1.5-2.5C region were classified as type II. In the type II histograms, the number of cells with ploidy of $>4.5 \mathrm{C}$ together with the cells of ploidy ranged from $2.5 \mathrm{C}$ to $3.5 \mathrm{C}$ (predominantly near-triploid range) was less than $10 \%$. The type III histograms represented highly proliferating cells $(>5 \%)$ that scattered between normal or near-normal $2 \mathrm{C}$ and $4 \mathrm{C}$ peak positions. Less than $5 \%$ of cells had $>4.5 \mathrm{C}$. The type IV histograms were characterized by a large fraction of aneuploid cells $(>5 \%)$ with increased and scattered DNA content significantly exceeding the normal $4 C$ peak position ( $>4.5 \mathrm{C}$ ). DNA histograms of types III and IV are indicative of the worst prognosis [16]. Ploidy-related parameters such as DNA index (DI) that characterizes aneuploidy and the percentages of cells exceeding $4.5 \mathrm{C}$ that characterize polyploidization were also determined. DI introduced by Barlogie et al. [21] was defined as the ratio of the modal DNA value of the abnormal cells in $\mathrm{G}_{1}$ to the modal DNA value of the normal diploid cells in $\mathrm{G}_{1}$.

\section{Immunofluorescence staining}

The imprints of surgically removed fresh tissue specimens were prepared on poly-Llysine-coated microscopy slides (Thermo Fisher Scientific) followed by fixation and staining according to the published procedures [19]. Samples were fixed in methanol at $-20^{\circ} \mathrm{C}$ for 7 min and dipped 10 times in ice-cold pure acetone. After fixation, samples were rinsed with Tris-buffered saline (TBS; pH 7.4) supplemented with $0.01 \%$ Tween 20 (washing solution abbreviated as TBST) $3 \times 5 \mathrm{~min}$ and blocked in TBS supplemented with $0.05 \%$ Tween 20 and $1 \%$ BSA at room temperature. After blocking, samples were covered with TBS, $0.025 \%$ Tween 20 , and $1 \%$ BSA, containing primary antibodies to Ki-67 (1:50, rabbit polyclonal, PA5-16785, Pierce), SOX2 (1:50, mouse monoclonal, MA1014, Pierce), NANOG (1:50, mouse monoclonal, N3038, Sigma), and incubated in a humidified chamber overnight at $4^{\circ} \mathrm{C}$. Then samples were washed with TBST $3 \times 5 \mathrm{~min}$ at room temperature and incubated for $40 \mathrm{~min}$ at room temperature in the dark with the appropriate secondary antibodies diluted in TBST: goat anti-mouse IgG Alexa Fluor 488 (1:300, A31619, Invitrogen) or goat anti-rabbit IgG Alexa Fluor 594 (1:300, A31631, Invitrogen). Finally, samples were rinsed with TBST $3 \times 5$ min followed by rinsing with phosphate buffered saline (PBS; pH 7.3) $1 \times 2$ min. To clearly visualize cell nuclei, samples were counterstained with DAPI (Sigma-Aldrich) at concentration of $0.25 \mu \mathrm{g} / \mathrm{ml}$ for $2 \mathrm{~min}$, rinsed with PBS, and embedded in the anti-fade reagent ProLong Gold (Invitrogen). As for staining of CD44, samples were fixed in $4 \%$ paraformaldehyde in PBS for 15 min at room temperature followed by rinsing them with PBS containing $0.1 \%$ glycine $3 \times 5$ min. All subsequent steps were identical to those described above. Dilution of the primary antibody to CD44 (rabbit polyclonal, HPA005785, Sigma) was 1:50.

\section{Results}

Table 1 presents the clinico-pathologic information for each of 12 breast cancer cases supplemented by corresponding tumor DNA content analysis data that were obtained before and after NAC. The cases categorized in this study as near-triploid $(\sim 3 C)$, whose $D I=1.26-1.74$ $(n=7)$, were those that had at least one $\sim 3 C$ clone in spite of persisting the clones of other ploidy. The rest of the cases were defined as near-euploid, whose DI values fall into the category of $<1.26$ and/or $>1.74(n=5)$. The reason why we focused on the 'triploid group' 


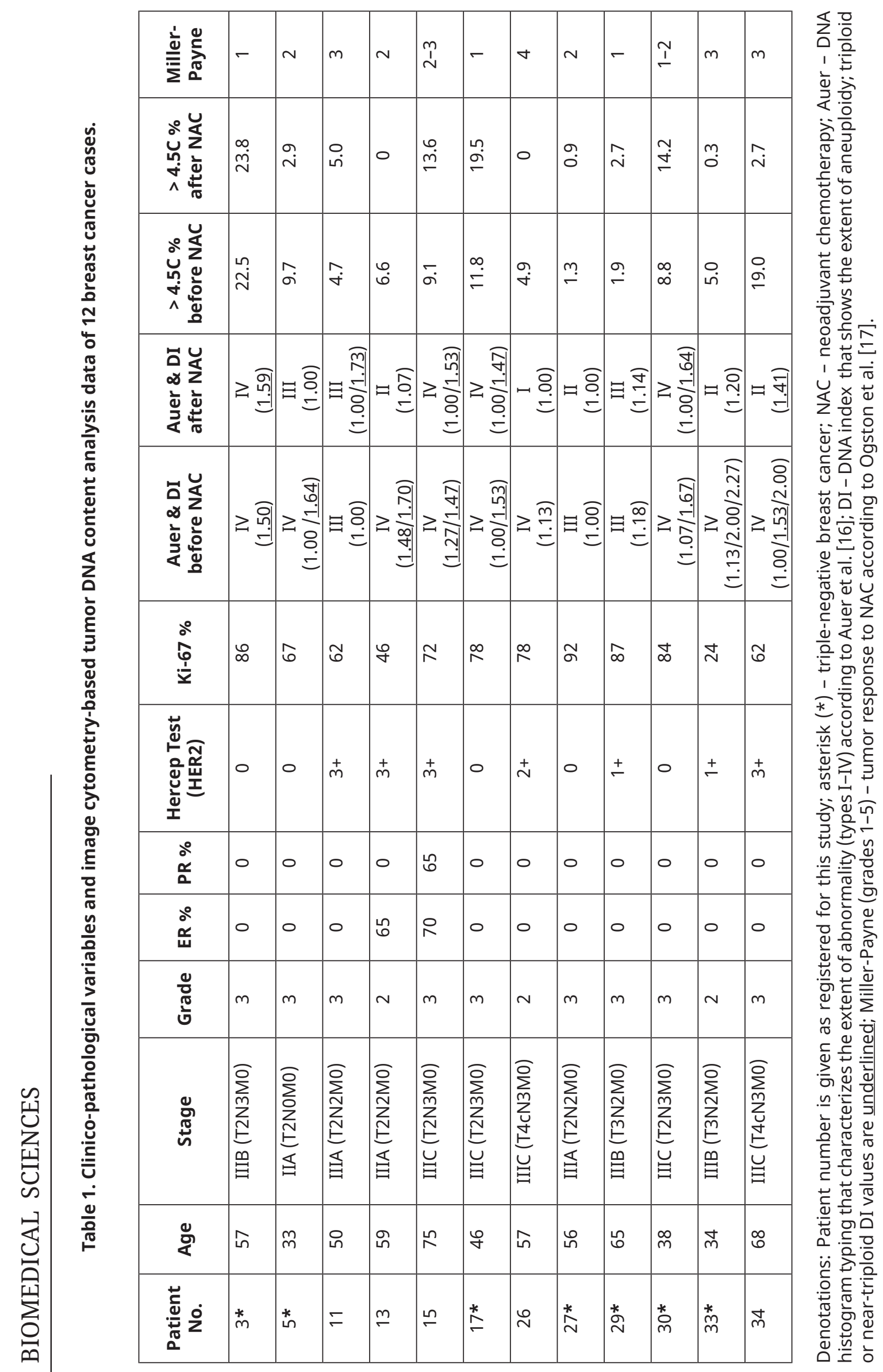

50 B.I. Gerashchenko et al. 
is that this category of patients compared with others was found to predominantly have highly malignant tumors leading to poor prognosis [14, 22-24]. In addition, the near-triploid cases can correlate with significant genomic gains $(>5 \mathrm{C}$ ) occurring presumably due to active proliferation of $\sim 3 C$ clones [22]. Although by examining diagnostic biopsies we did find an apparent increase in the number of $>4.5 \mathrm{C}$ cells in near-triploid tumors compared with neareuploid ones (Fig. 1A), this finding was not clearly attributed to the enhanced proliferation of tumor cells, as evidenced by the results of counting of Ki-67-positive cells in both groups (Fig. 1B). Perhaps, much larger cohort of data is needed to delineate the role of tumor cell proliferation (particularly proliferation of $\sim 3 C$ clones) in gaining the numbers of $>4.5 \mathrm{C}$ cells. Because an increase in the number of $>4.5 \mathrm{C}$ cells assuming polyploidization is indicative of tumor aggressiveness and poor disease outcome, it seems reasonable to clarify whether NAC can eliminate them or considerably reduce their presence. Figure 2A shows that NAC completely eliminated $>4.5 \mathrm{C}$ cells in 2 cases ( 13 and 26 ) and considerably reduced the percentage of such cells in 3 cases $\left(5 *, 33^{*}\right.$, and 34 ), suggesting the apparent positive effect of NAC in 5 of 12 cases regardless of the ploidy group they belong to. However, among other 7 non-responsive cases $(3 *, 11,15,17 *, 27 *$, $29 *$, and $30 *)$, there were 3 cases $(15,17 *$, and $30 *$ ) that distinctly showed enhanced polyploidization, as evidenced by a significant increase in percentages of $>4.5 \mathrm{C}$ cells,

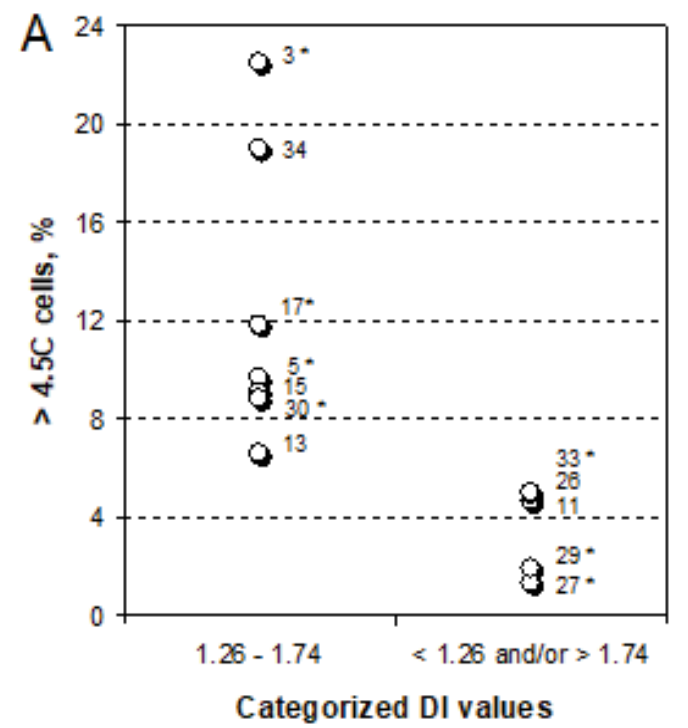

suggesting the negative (opposite) NAC effect. All those 5 aforementioned cases that were responsive to NAC showed the improved DNA content profiles evaluated according to Auer (Fig. 2B). Notably, the only one case (27*) of all non-responsive cases showed an improvement in DNA histogram from type III to type II. To demonstrate whether Auer DNA histogram typing data can correlate with Miller-Payne histopathologic scoring data, Figure 3 shows both of these parameters well interrelated. A distinct group of TNBC $(3 *, 5 *, 17 *, 29 *$, and $30 *$ ) is likely to be the most resistant to NAC, and all cases in this group except the case 29* belong to the near-triploid class. Although the case 27 * showed an improved DNA histogram (Fig. 2B), this one had the low grade 2 (MillerPayne scale, Fig. 3) confirming its resistance to NAC. As for the case 13 that was well responsive to NAC (Figs. 2A and 2B), this one, however, like the case $27^{*}$, had the low grade 2 (Miller-Payne scale, Fig. 3). Of all 12 cases, the best therapeutic effects were achieved with regard to the neareuploid case 26, which was not TNBC (Auer type I vs. Miller-Payne grade 4, Fig. 3). Regrettably, pCR was not achieved in all these cases because none of them had the highest Miller-Payne grade 5 .

\section{Discussion}

Thus, the Auer types of DNA content profiles of post-NAC breast cancer cases were generally in agreement with corresponding Miller-Payne histopathologic grades, but quantification of $>4.5 \mathrm{C}$ cells seems superior in terms of identi-

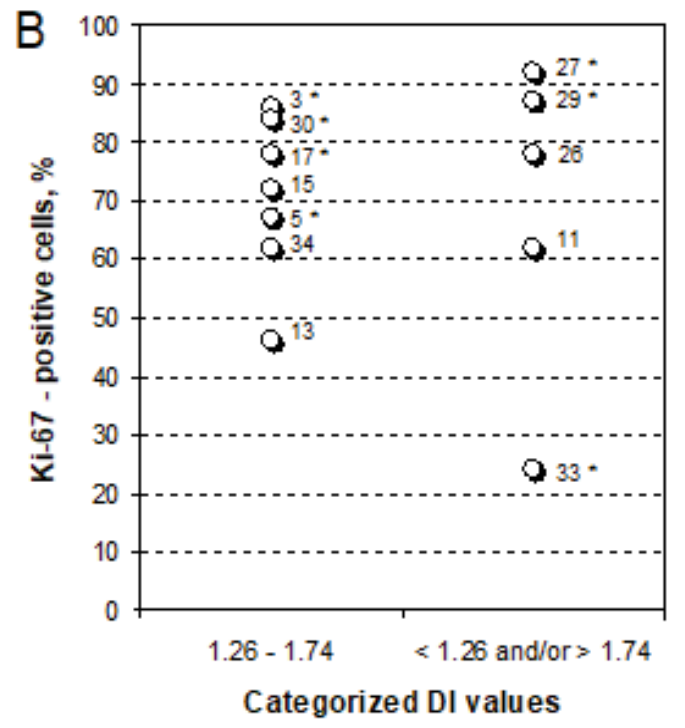

Fig. 1. Percentages of $>4.5 \mathrm{C}$ cells $(A)$ and Ki-67-positive cells $(B)$ in near-triploid (DI values are ranged from 1.26 to 1.74 ) or near-euploid (DI values are $<1.26$ and/or $>1.74$ ) breast cancer cases before NAC. Asterisks (*) denote triple-negative breast cancer. 

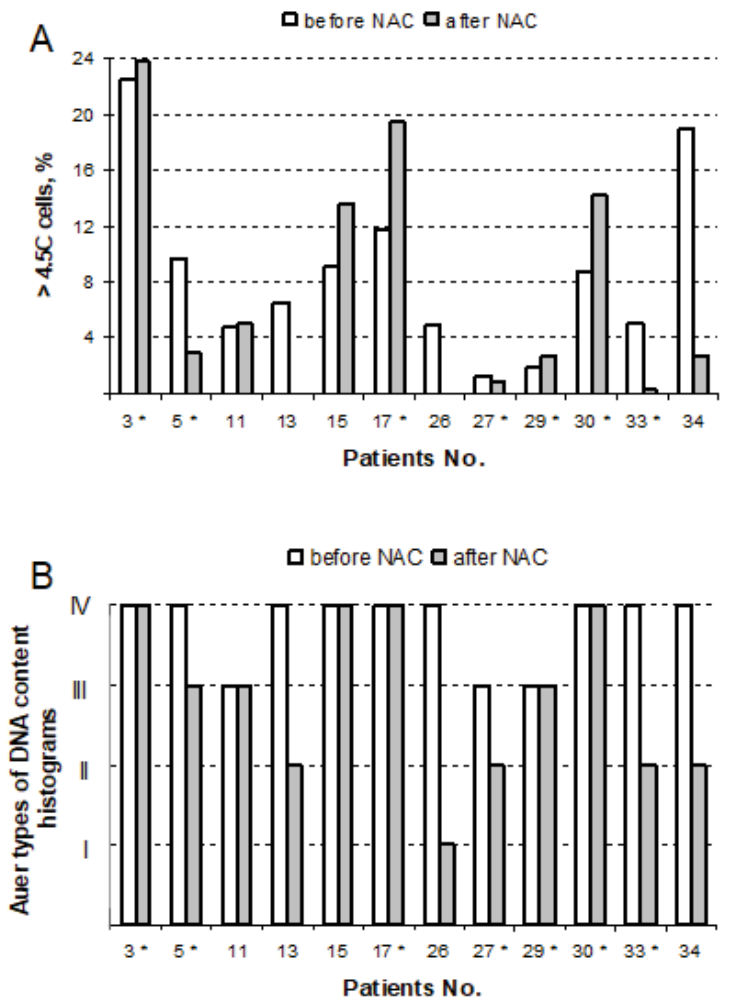

Fig. 2. Effects of NAC on percentages of $>4.5 \mathrm{C}$ cells (A) and DNA content profiles (typed according to Auer) (B) in each of breast cancer cases. Asterisks $(*)$ denote triple-negative breast cancer.

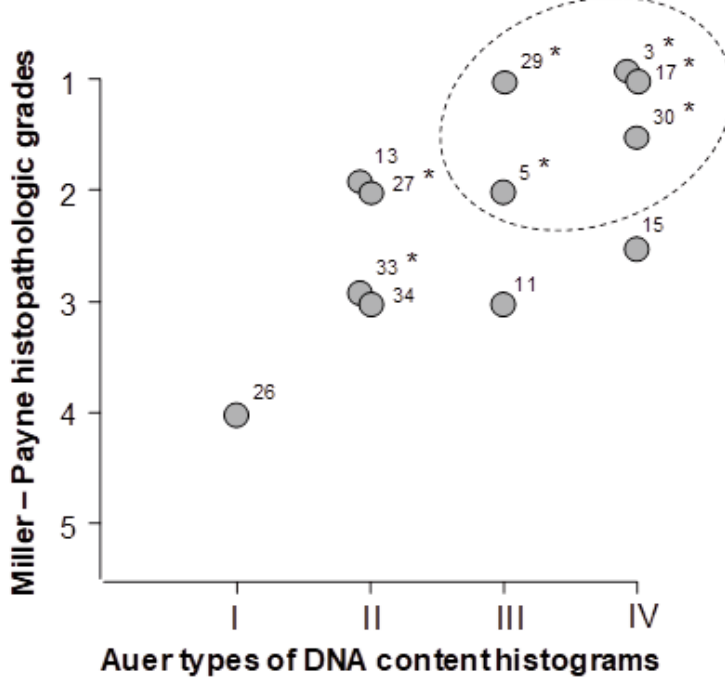

Fig. 3. Mapping of 12 breast cancer cases based on Auer typing of tumor DNA content histograms (after NAC) vs. Miller-Payne histopathologic scoring. Auer scale presents the types of histograms (I-IV), while Miller-Payne scale presents the histopathologic grades (1-5). Most resistant cases are encircled. Asterisks (*) denote triple-negative breast cancer.

fication of those cases that show the negative NAC effect (in this study those cases were 15, $17 *$, and $30 *)$. Polyploidization that in some non-responsive cases was gained by NAC is likely to be attributed to $3 \mathrm{C}$ clones. The most of non-responsive cases examined here are near-triploid TNBC, of which one case should especially be pointed out. This is the case 17*, which substantially differs from the rest of nonresponsive cases in terms of spectacular postNAC polyploidization of predominant $3 \mathrm{C}$ tumor cells resulting in the growth of the fraction of 

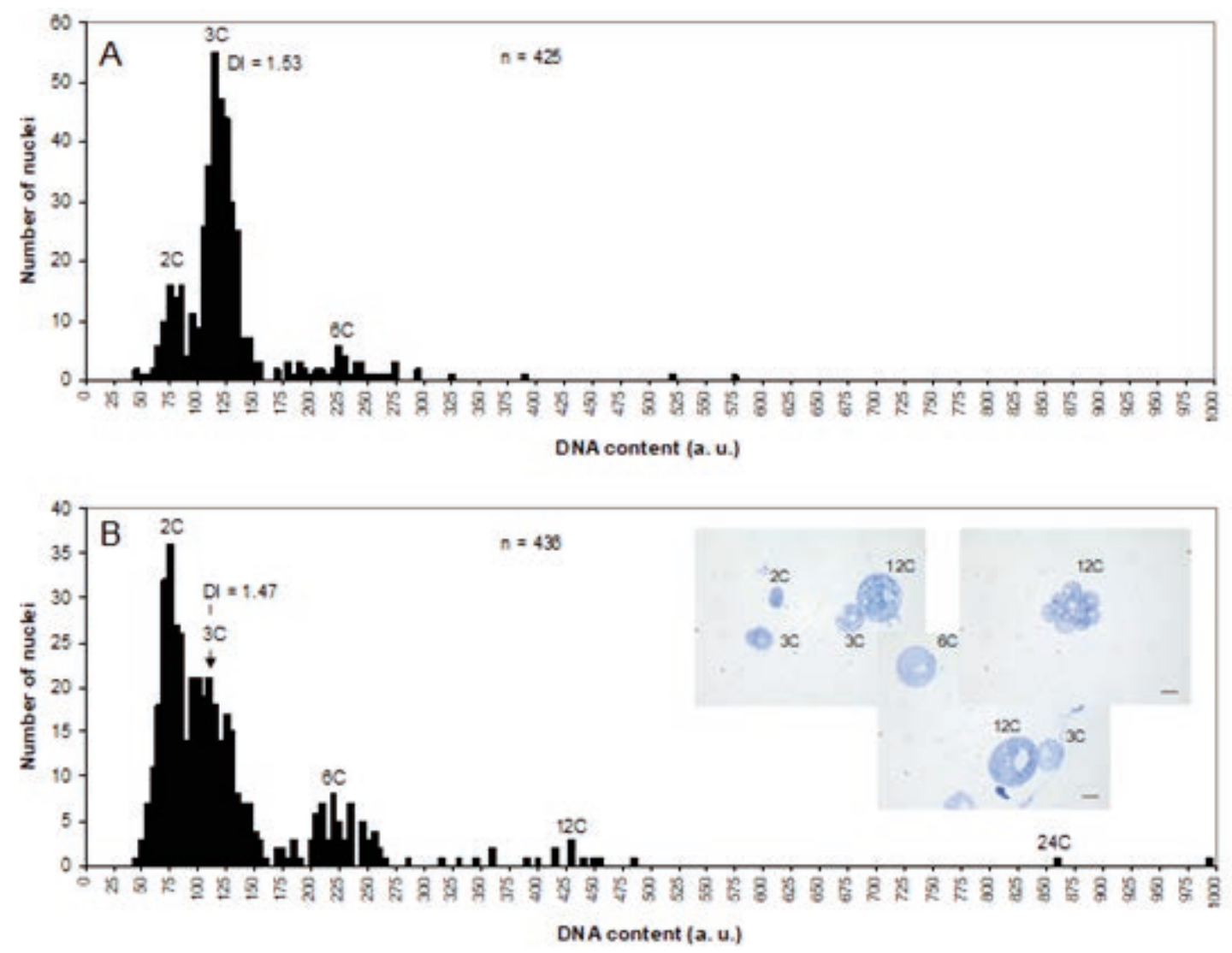

Fig. 4. DNA content histograms of a triple-negative case (patient $17^{*}$ ) before NAC (A) and after NAC accompanied with microphotographs of TB-stained nuclei (scale bars $=10 \mu \mathrm{m})(B)$.

6C cells accompanied by the appearance of additional fractions of $12 \mathrm{C}$ and $24 \mathrm{C}$ cells generated due to ploidy doublings (Fig. 4A vs. Fig. 4B). A significant increase of the fraction of 2C cells (Fig. 4B) may take place due to depolyploidization [25]. Microscopic examination of the operation material obtained after NAC revealed the existence of multinucleated cells, although those ones were rarely seen (Fig. 4B). In this particular case $(17 *)$, like in some other non-responsive cases, cells with large nuclei were often observed as Ki-67-positive (Fig. 5A), supporting the assumption that these cells are capable of cycling. Among CD44-positive cells, cells with large nuclei were widely present as well (Fig. 5B), suggesting their invasive potential. Moreover, $\sim 80 \%$ of $2 \mathrm{C}$ cells that may represent descendants of de-polyploidizing cells were CD44-positive. In basal-like breast cancers, of which $77 \%$ are TNBC [26], CD44-positive tumor cells that can potentially be associated with cancer stem cell phenotype are characteristic of highly aggressive tumors with enhanced invasiveness [27, 28]. Generation of drugresistant polyploid tumor cells gaining mesenchymal characteristics with elevated expression of cancer stem cell markers (CD44 and CD133) has been reported [29]. In addition to the expression of Ki-67 and CD44, many cells with large or small nuclei (up to $75 \%$ ) can express self-renewal factors characteristic for stem cells, such as SOX2 and NANOG (Figs. 5C-D and Figs. 5E-F, respectively). Notably, stress-induced polyploidization of tumor cells (including breast cancer cells) expressing self-renewal factors was also demonstrated in vitro in other studies by several groups of researchers, prompting us to suppose that the polyploid cells and their descendants released by de-polyploidization can possess stem cell features [30-33]. This type of stem cell-like gene expression signature is characteristic of poorly differentiated aggressive tumors including breast cancer often of basallike subtype [34]. Interestingly, ionizing radiation may induce a breast cancer stem-cell phenotype $\mathrm{CD} 44^{+} / \mathrm{CD} 24^{-/ \text {low }}$ in differentiated breast cancer cells with the involvement of polyploid cells that express OCT4, SOX2, NANOG, and KLF4, in a dose-dependent manner [32]. The number of examples demonstrating radio- or chemotherapy-induced either stem-like and/or therapy-resistant state in 

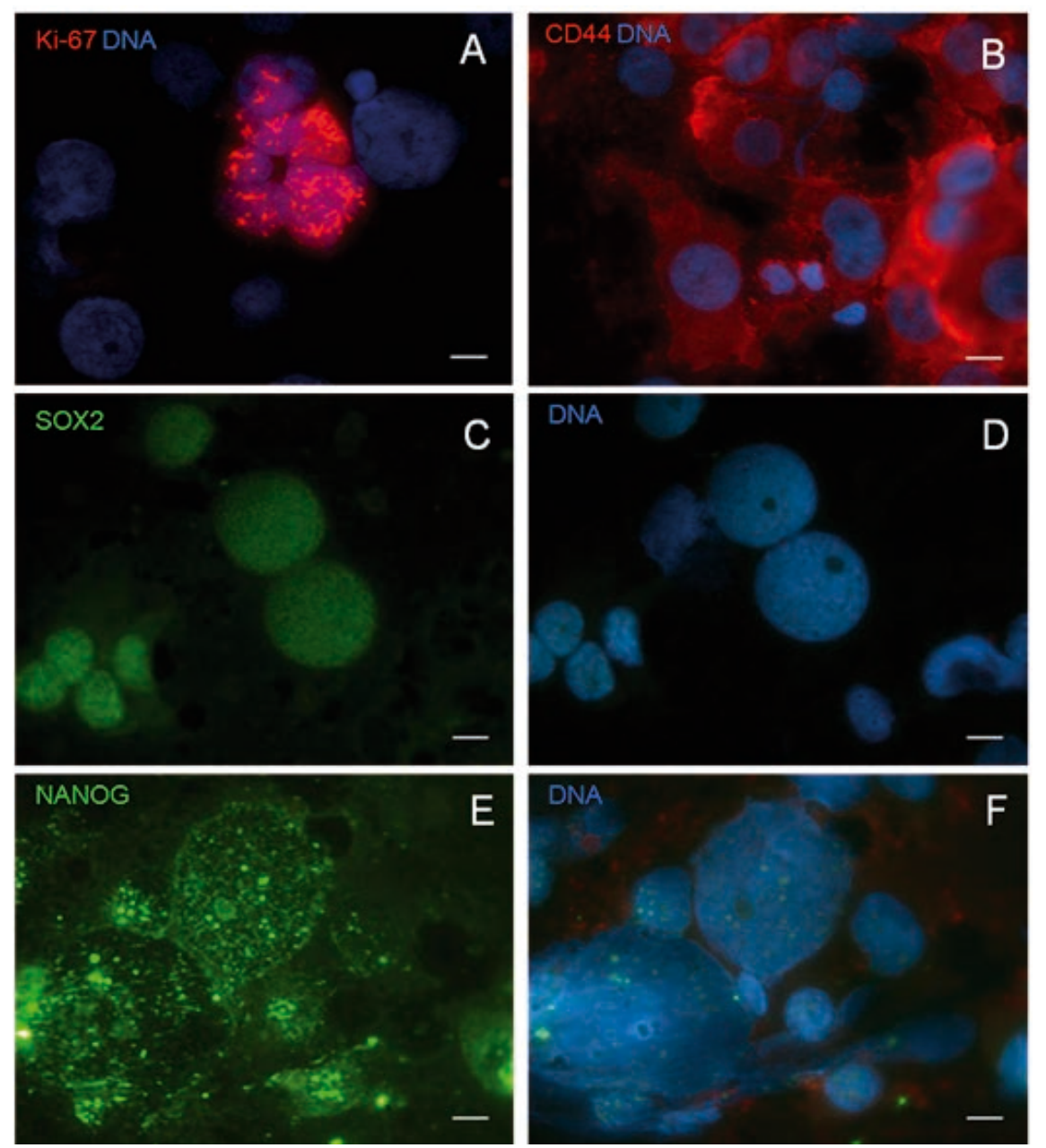

Fig. 5. Microphotographs of immunofluorescence-stained imprints of the surgical post-NAC material of patient 17* depicting cells positive for Ki-67, CD44, SOX2 and NANOG. (A) A group of large nuclei expressing Ki-67 in 15\% of all Ki-67-positively stained nuclei. (B) Among CD44-positive cells (45\%) there are many cells with large nuclei. (C, D) Among SOX2-positive cells (75\%) there are many cells with large nuclei. (E, F) Among NANOG-positive cells (75\%) there are many cells with large nuclei (in this image, two largest nuclei may have 24C). All immunofluorescence preparations were counterstained with DAPI for DNA. Scale bars $=10 \mu \mathrm{m}$.

tumor cells is growing $[15,35,36]$. A recent study of TNBC has shown that pre-existing subclones can be adaptively selected by NAC (adaptive resistance), followed by transcriptional reprogramming to evolve the resistant phenotypes [15].

\section{Conclusions}

DNA content profiling provides a facile, prompt, and accurate means of interpreting therapeutic responses in NAC-treated breast cancers. Because NAC effects for some breast cancers may be negative, the use of the further treatment strategy should be carefully considered. Therapy-resistant polyploid tumor cells possessing stem cell features can be induced in vivo as well, assuming that this process is not autonomous, but rather stipulated by the tumor microenvironment and intra-tumor heterogeneity. These polyploid cells are not quiescent and they manifest the invasiveness phenotype that together with stemness are also seen in descendants after de-polyploidization.

\section{Acknowledgments}

This work was performed within the frame of the project supported by the European Social Fund (grant number: 2013/0023/1DP/1.1.1.2.0/ 13/APIA/VIAA/037).

\section{Conflict of interest}

The authors declare no conflict of interest. 


\title{
ОЦІНКА ВІДПОВІДІ РАКУ МОЛОЧНОЇ ЗАЛОЗИ НА ПРОТИПУХЛИННУ ТЕРАПІЮ ЗА ДАНИМИ ДНК-ЦИТОМЕТРІї
}

\author{
Б.I. Геращенко ${ }^{1}$, K. Salmina², J. Eglītis ${ }^{3}$, J. Ërenpreisa ${ }^{2}$ \\ 1 - ІНСТИТУТ ЕКСПЕРИМЕНТАЛЬНОЇ ПАТОЛОГІЇ, ОНКОЛОГІЇ І РАДІОБІОЛОГІЇ \\ IMEHI Р.Є. КАВЕЦЬКОГО НАН УКРАЇНИ, КИЇВ, УКРӒ̈НА \\ 2 - LATVIAN BIOMEDICAL RESEARCH AND STUDY CENTRE, RIGA, LATVIA \\ 3 - UNIVERSITY OF LATVIA, RIGA, LATVIA
}

Вступ. Розбіжності в інтерпретації відповіді раку молочної залози (РМз) на протипухлинну терапію все ще існують переважно через відсутність стандартизованих критеріїв оцінки та методів.

Мета роботи. Оцінка ефективності застосування профілювання вмісту днК у клітинах РМз до $i$ після неоад'ювантної хіміотерапії (НХT) для спрощення інтерпретації терапевтичного ефекту.

Методи. Препарати діагностичної біопсії та операційного матеріалу (тканини первинних пухлин, хірургічно видалених після НХТ), досліджували за допомогою ДНК-цитометрії. Поліплоїдію та анеуплоїдію у ДНК гістограмах оцінювали застосовуючи прогностичну типізацію Ауера. На тих же гістограмах визначали ДНК індекси (DI) клітинних клонів і відсотки поліплоїдизуючих клітин (>4.5C). Імунофлуоресцентне забарвлення застосовували для оцінки проліферації (Кі-67), інвазивності (CD44) та факторів самооновлення, притаманних стовбуровим клітинам (SOX2 ma NANOG).

Результати. Профілювання вмісту ДНК 12 випадків РМЗ, з яких 7 були тричі-негативними, виявило ознаки нечутливості пухлини до НХТ у 7 випадках, з яких 5 були тричі-негативними. Серед нечутливих до НХТ випадків були 3 випадки, які показали посилену поліплоїдизацію, що свідчить про негативний ефект HXT. Пара-триплоїдні (DI = 1.26-1.74) тричі-негативні випадки визначені як найбільш резистентні до НХТ. Проліферуючі пара-триплоїдні клітини можуть призводити до зростання кількості поліплоїдних клітин позитивних на Кі-67, CD44, SOX2 і NANOG.

Висновки. Дані ДНК-цитометрії забезпечують додатковою корисною інформацією для інтерпретації відповіді раку молочної залози РМЗ на протипухлинну терапію. Поліплоїдні пухлинні клітини з особливостями стовбурових клітин можуть бути індуковані НХТ. Оскільки в деяких випадках НХТ може викликати несприятливу відповідь пухлин, стратегію подальшої протипухлинної терапії необхідно ретельно переглянути.

КЛЮчОВІ СЛОВА: рак молочної залози; поліплоїдні клітини; пара-триплоїдія; ДНКцитометрія; терапевтичний ефект; стовбурові клітини раку.

\section{Інформація про авторів}

Геращенко Богдан Іванович - канд. біол. наук, відділ засобів та методів сорбційної терапії, Інститут експериментальної патології, онкології і радіобіології ім. Р.Є. Кавецького НАНУ, вул. Васильківська 45, Київ 03022, Україна.

\section{Information about authors}

Bogdan I. Gerashchenko - MD, Ph.D., Department of Means and Methods of Sorption Therapy, R.E. Kavetsky Institute of Experimental Pathology, Oncology and Radiobiology of NASU, 45 Vasylkivska Str., Kyiv 03022, Ukraine.

ORCID 0000-0001-6404-2320, e-mail: biger63@yahoo.com

Kristine Salmina - Ph.D., Cancer Research Laboratory, Latvian Biomedical Research and Study Centre, 1 Ratsupites Str., Riga, LV-1067, Latvia.

ORCID 0000-0002-8994-773X, e-mail: salmina.kristine@gmail.com

Janis Eglitis - MD, Ph.D., Faculty of Medicine, University of Latvia, 3 Jelgavas Str., Riga, LV-1004, Latvia. ORCID 0000-0002-8784-1544, e-mail: dreglitis@gmail.com

Jekaterina Erenpreisa - Dr. habil. med., Cancer Research Laboratory, Latvian Biomedical Research and Study Centre, 1 Ratsupites Str., Riga, LV-1067, Latvia.

ORCID 0000-0002-2870-7775, e-mail: katrina@biomed.lu.Iv 


\section{References}

1. Ragaz J, Baird R, Rebbeck P, Goldie J, Coldman A, Spinelli J. Neoadjuvant (preoperative) chemotherapy for breast cancer. Cancer 1985; 56: 719-724.

doi: $10.1002 / 1097-0142(19850815)$ 56:4<719::AID-CNCR2820560403>3.0.CO;2-W

2. Buchholz TA, Hunt KK, Whitman GJ, Sahin AA, Hortobagyi GN. Neoadjuvant chemotherapy for breast carcinoma: Multidisciplinary considerations of benefits and risks. Cancer 2003; 98: 1150-1160.

doi: 10.1002/cncr.11603

3. Sahoo S, Lester SC. Pathology of breast carcinomas after neoadjuvant chemotherapy: An overview with recommendations on specimen processing and reporting. Arch Pathol Lab Med 2009; 133: 633-642.

https://www.ncbi.nlm.nih.gov/pubmed/19391665

4. Horii R, Akiyama F. Histological assessment of therapeutic response in breast cancer. Breast Cancer 2016; 23: 540-545.

doi: $10.1007 / \mathrm{s} 12282-013-0499-6$

5. Sahoo S, Lester SC. Pathology considerations in patients treated with neoadjuvant chemotherapy. Surg Pathol Clin 2012; 5: 749-774.

doi: 10.1016/j.path.2012.06.005

6. Kuroi K, Toi M, Tsuda H, Kurosumi M, Akiyama F. Issues in the assessment of the pathologic effect of primary systemic therapy for breast cancer. Breast cancer 2006; 13: 38-48.

doi: $10.2325 /$ jbcs. 13.38

7. Weaver BAA, Cleveland DM. Does aneuploidy cause cancer? Curr Opin Cell Biol 2006; 18: 658-667. doi: 10.1016/j.ceb.2006.10.002

8. Gordon DJ, Resio B, Pellman D. Causes and consequences of aneuploidy in cancer. Nat Rev Genet 2012; 13: 189-203.

doi: $10.1038 / \mathrm{nrg} 3123$

9. Swanton C, Nicke B, Schuett M, Eklund AC, $\mathrm{Ng} \mathrm{C}$, Li Q, et al. Chromosomal instability determines taxane response. Proc Natl Acad Sci U S A 2009; 106: 8671-8676.

doi: $10.1073 /$ pnas.0811835106

10. Martelotto LG, Ng CKY, Piscuoglio S, Weigelt B, Reis-FilhoJS. Breast cancer intra-tumor heterogeneity. Breast Cancer Res 2014; 16: R48.

doi: $10.1186 /$ bcr3658

11. McGranahan N, Swanton C. Clonal heterogeneity and tumor evolution: Past, present, and the future. Cell 2017; 168: 613-628.

doi: 10.1016/j.cell.2017.01.018

12. Gerashchenko BI, Huna A, Erenpreisa J. Characterization of breast cancer DNA content profiles as a prognostic tool. Exp Oncol 2014; 36: 219-225.

https://www.ncbi.nlm.nih.gov/pubmed/25537213

13. Coward J, Harding A. Size does matter: Why polyploid tumor cells are critical drug targets in the war on cancer. Front Oncol 2014; 4: Article 123.

doi: 10.3389/fonc.2014.00123

14. Dayal JHS, Sales MJ, Corver WE, Purdie CA, Jordan LB, Quinlan PR, et al. Multiparameter DNA content analysis identifies distinct groups in primary breast cancer. Br J Cancer 2013; 108: 873-880.

doi: 10.1038/bjc.2013.42

15. Kim C, Gao R, Sei E, Brandt R, Hartman J, Hatschek T, et al. Chemoresistance evolution in triple-negative breast cancer delineated by singlecell sequencing. Cell 2018; 173: 879-893.

doi: 10.1016/j.cell.2018.03.041

16. Auer GU, Caspersson TO, Wallgren AS. DNA content and survival in mammary carcinoma. Anal Quant Cytol 1980; 2: 161-165.

https://www.ncbi.nlm.nih.gov/pubmed/6252802

17. Ogston KN, Miller ID, Payne S, Hutcheon AW, Sarkar TK, Smith I, et al. A new histological grading system to assess response of breast cancers to primary chemotherapy: prognostic significance and survival. Breast 2003; 12: 320-327.

doi: 10.1016/S0960-9776(03)00106-1

18. Erenpreisa J, Freivalds T. Anisotropic staining of apurinic acid with toluidine blue. Histochemistry 1979; 60: 321-325.

doi: 10.1007/BF00500660

19. Gerashchenko BI, Salmina K, Eglitis J, Huna A, Grjunberga V, Erenpreisa J. Disentangling the aneuploidy and senescence paradoxes: A study of triploid breast cancers non-responsive to neoadjuvant therapy. Histochem Cell Biol 2016; 145: 497-508.

doi: 10.1007/s00418-016-1415-x

20. Haroske G, Baak JPA, Danielsen H, Giroud F, Gschwendtner A, Oberholzer M, et al. Fourth updated ESACP consensus report on diagnostic DNA image cytometry. Anal Cell Pathol 2001; 23: 89-95.

doi: $10.1155 / 2001 / 657642$

21. Barlogie B, Hittelman W, Spitzer G, TrujilloJM, Hart JS, Smallwood L, et al. Correlation of DNA distribution abnormalities with cytogenetic findings in human adult leukemia and lymphoma. Cancer Res 1977; 37: 4400-4407.

http://cancerres.aacrjournals.org/content/ canres/37/12/4400.full.pdf

22. Fallenius AG, Auer GU, Carstensen JM. Prognostic significance of DNA measurements in 409 consecutive breast cancer patients. Cancer 1988; 62: 331-341.

doi: $10.1002 / 1097-0142(19880715)$ 62:2<331::AID-CNCR2820620218>3.0.CO;2-8

23. Leonardi E, Cristofori A, Caffo O, Dalla Palma P. Cytometric DNA analysis and prognostic biomarkers in breast carcinoma. Expression of P53 product in the different ploidy classes. Anal Cell Pathol 1997; 15: 31-45.

doi: $10.1155 / 1997 / 345949$

24. Schulze S, Petersen I. Gender and ploidy in cancer survival. Cell Oncol 2011; 34: 199-208.

doi: 10.1007/s13402-011-0013-0

25. Erenpreisa J, Salmina K, Huna A, Kosmacek EA, Cragg MS, Ianzini F, et al. Polyploid tumour cells elicit paradiploid progeny through depolyploidizing divisions and regulated autophagic degradation. Cell Biol Int 2011; 35: 687-695.

doi: $10.1042 / C B I 20100762$ 
26. Bertucci F, Finetti P, Cervera N, Esterni B, Hermitte $F$, Viens $P$, et al. How basal are triplenegative breast cancers? Int J Cancer 2008; 123: 236-240.

doi: 10.1002/ijc.23518

27. Sheridan C, Kishimoto H, Fuchs RK, Mehrotra S, Bhat-Nakshatri P, Turner $\mathrm{CH}$, et al. CD44 ${ }^{+} / \mathrm{CD}^{-} 4^{-}$breast cancer cells exhibit enhanced invasive properties: An early step necessary for metastasis. Breast Cancer Res 2006; 8: R59. doi: $10.1186 /$ bcr1610

28. Mani SA, Guo W, Liao M-J, Eaton EN, Ayyanan A, Zhou AY, et al. The epithelialmesenchymal transition generates cells with properties of stem cells. Cell 2008; 133: 704-715. doi: 10.1016/j.cell.2008.03.027

29. Zhang S, Mercado-Uribe I, Xing Z, Sun B, Kuang J, Liu J. Generation of cancer stem-like cells through the formation of polyploid giant cancer cells. Oncogene 2014; 33: 116-128.

doi: 10.1038/onc.2013.96

30. Salmina K, Jankevics E, Huna A, Perminov D, Radovica I, Klymenko T, et al. Upregulation of the embryonic self-renewal network through reversible polyploidy in irradiated p53-mutant tumor cells. Exp Cell Res 2010; 316: 2099-2112.

doi: 10.1016/j.yexcr.2010.04.030
31. Ghisolfi L, Keates AC, Hu X, Lee D, Li CJ. Ionizing radiation induces stemness in cancer cells. PLOS ONE 2012; 7: e43628.

doi: 10.1371/journal.pone.0043628

32. Lagadec C, Vlashi E, Della Donna L, Dekmezian C, Pajonk F. Radiation-induced reprogramming of breast cancer cells. Stem Cells 2012; 30: 833-844.

doi: $10.1002 /$ stem. 1058

33. Niu N, Mercado-Uribe I, Liu J. Dedifferentiation into blastomere-like cancer stem cells via formation of polyploid giant cancer cells. Oncogene 2017; 36: 4887-4900.

doi: 10.1038 /onc. 2017.72

34. Ben-Porath I, Thomson MW, Carey VJ, Ge R, Bell GW, Regev A, et al. An embryonic stem cell-like gene expression signature in poorly differentiated human tumors. Nat Genet 2008; 40: 499-507.

https://doi: 10.1038/ng.127

35. Pisco AO, Huang S. Non-genetic cancer cell plasticity and therapy-induced stemness in tumour relapse: "What does not kill me strengthens me". Br J Cancer 2015; 112: 1725-1732. doi: 10.1038/bjc.2015.146

36. Mirzayans R, Andrais B, Murray D. Roles of polyploid/multinucleated giant cancer cells in metastasis and disease relapse following anticancer treatment. Cancers 2018; 10: 118. doi: $10.3390 /$ cancers 10040118

Received 06 February 2019; revised 07 March 2019; accepted 28 March 2019.

This is an open access article distributed under the Creative Commons Attribution License, which permits unrestricted use, distribution, and reproduction in any medium, provided the original work is properly cited. 